LO CKREED MATTIY

ENVIRONMENTAL RESTORATION PROGRAM
MANAGEDBY

LOCKHEED MARTIN ENERGY SYSTEMS, INC. FOR THE UNITED STATES DEPARTMENT OF ENERGY

\section{Final Report for the Central_Mercury Treatment System in Building 9623 at the Oak Ridge Y-12 Plant, Oak Ridge, Tennessee}

\author{
RECEIVED \\ FFR 2819997 \\ OSTI
}

:

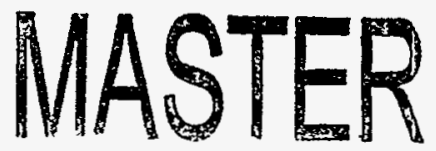

This document has been approved by the Y-12 Plant Technical Information Office for release to the public. Date: $1 / 9 / 97$

ENERGY SYSTEMS 
Energy Systems Environmental Restoration Program

\author{
Final Report for the Central Mercury \\ Treatment System in Building 9623 \\ at the Oak Ridge Y-12 Plant, \\ Oak Ridge, Tennessee
}

Date Issued-February 1997

\title{
DISCLAIMER
}

This report was prepared as an account of work sponsored by an agency of the United States Government. Neither the United States Government nor any agency thereof, nor any of their employees, makes any warranty, express or implied, or assumes any legal liability or responsibility for the accuracy, completeness, or usefulness of any information, apparatus, product, or process disclosed, or represents that its use would not infringe privately owned rights. Reference herein to any specific commercial product, process, or service by trade name, trademark, manufacturer, or otherwise does not necessarily constitute or imply its endorsement, recommendation, or favoring by the United States Government or any agency thereof. The views and opinions of authors expressed herein do not necessarily state or reflect those of the United States Government or any agency thereof.

\author{
Prepared for the \\ U.S. Department of Energy \\ Office of Environmental Management \\ under budget and reporting code EW 20 \\ Environmental Management Activities at the \\ OAK RIDGE Y-12 PLANT \\ Oak Ridge, Tennessee 37831 \\ managed by \\ LOCKHEED MARTIN ENERGY SYSTEMS, INC. \\ for the \\ U.S. DEPARTMENT OF ENERGY \\ under contract DE-AC05-84OR21400
}




\section{DISCLAMMER}

Portions of this document may be illegible in electronic image products. Images are produced from the best available original document. 


\section{PREFACE}

Final Report for the Central Mercury Treatment System in Building 9623 at the Oak Ridge Y-12 Plant, Oak Ridge, Tennessee (Y/ER-282) discusses the construction of the Central Mercury Treatment System (CMTS) in Building 9623 at the Y-12 Plant, the remediation activities involved, waste generated from the project, and the monitoring schedule of the CMTS. The CMTS is part of the Reduction of Mercury in Plant Effluent Program. The project treats groundwater contaminated with mercury from Bldgs. 9201-4, 9201-5, and 9204-4 at the Y-12 Plant to meet National Pollutant Discharge Elimination System Permit limits for discharge to East Fork Poplar Creek. This work was performed under Work Breakdown Structure 1.4.12.1.1.03.44.20.40 (Activity Data Sheet 2300). 


\section{CONTENTS}

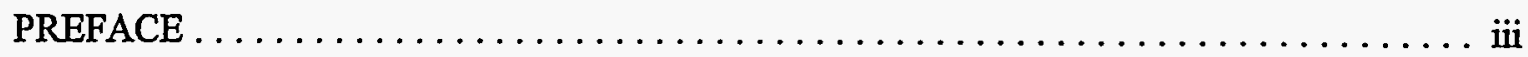
EXECUTIVE SUMMARY $\ldots \ldots \ldots \ldots \ldots \ldots \ldots \ldots \ldots \ldots \ldots \ldots \ldots \ldots$

1. PROJECT DESCRIPTION $\ldots \ldots \ldots \ldots \ldots \ldots \ldots \ldots \ldots \ldots \ldots \ldots \ldots \ldots \ldots \ldots$

2. PROJECT REQUIREMENTS $\ldots \ldots \ldots \ldots \ldots \ldots \ldots \ldots \ldots \ldots \ldots \ldots \ldots \ldots$

3. REMEDIATION ACTIVITIES $\ldots \ldots \ldots \ldots \ldots \ldots \ldots \ldots \ldots \ldots \ldots \ldots \ldots \ldots \ldots$

4. DEVIATIONS FROM APPROVED PLANS $\ldots \ldots \ldots \ldots \ldots \ldots \ldots \ldots \ldots \ldots \ldots \ldots$

5. WASTE MANAGEMENT/TRANSPORTATION ACTIVITIES $\ldots \ldots \ldots \ldots \ldots \ldots$

6. OPERATION AND MAINTENANCE PLANS $\ldots \ldots \ldots \ldots \ldots \ldots \ldots \ldots \ldots \ldots \ldots$

7. MONITORING SCHEDULE AND/OR EXPECTATIONS $\ldots \ldots \ldots \ldots \ldots \ldots \ldots$

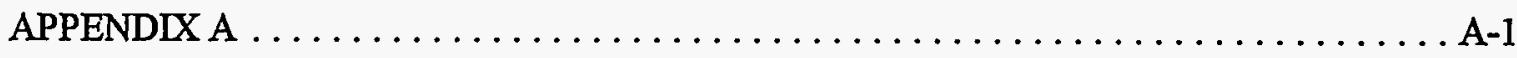

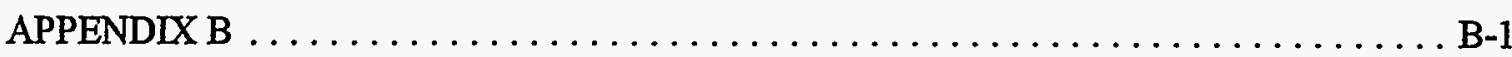

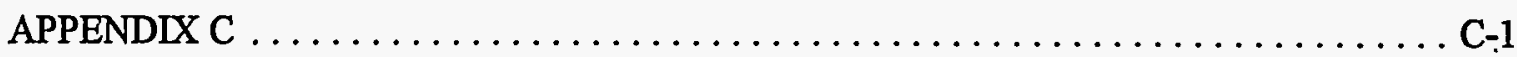

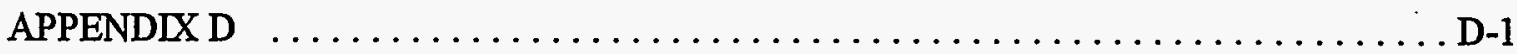




\section{EXECUTIVE SUMMARY}

This document discusses the construction of the Central Mercury Treatment System (CMTS) in Bldg. 9623 at the Y-12 Plant, the remediation activities involved, waste generated from the project, and the monitoring schedule of the CMTS. As part of the Reduction of Mercury in Plant Effluent Program, the project treats groundwater contaminated with mercury from Bldgs. 9201-4, 9201-5, and 9204-4 at the Y-12 Plant to meet National Pollutant Discharge Elimination System (NPDES) Permit limits for discharge to East Fork Poplar Creek.

The CMTS, located in Bldg. 9623, will treat water from the sumps of buildings in which mercury was used in operations and which have been shown to be significant contributors to the overall levels of mercury in plant effluents. This project was anticipated when the NPDES Permit was issued, and the contamination limits and frequency of monitoring for the system discharge are detailed in the permit as Outfall 551.

This project was performed as an Incentive Task Order and included the advance procurement of the carbon columns, removal of existing equipment in Bldg. 9623, and system installation and checkout. Construction activities for installing the system started in January 1996 after the area in Bldg. 9623 had been cleared of existing, obsolete equipment.

The CMTS became operational on November 26, 1996, well ahead of the permit start date of January 1,1998 . The early completion date allows $\mathrm{Hg}$ concentrations in EFPC to be evaluated to determine whether further actions are required to meet NPDES permit limits for reduced $\mathrm{Hg}$ loading to the creek. 


\section{PROJECT DESCRIPTION}

This project resulted in the construction of a Central Mercury Treatment System (CMTS) in Building 9623 at the Y-12 Plant to meet the discharge requirements for Outfall 551 as stated in the National Pollutant Discharge Elimination System (NPDES) permit (Permit \#TN0002968) dated April 28, 1995. This project is a part of the Reduction of Mercury in Plant Effluent Program.

The CMTS treats sump water from Bldgs. 9201-4, 9201-5, and 9204-4, which were formerly used for operations involving mercury. The project also included

- advanced procurement of the treatment system carbon columns,

- demolition and removal of unused equipment in Bldg. 9623, and

- installation of the columns including all support systems and piping required from the 2100-U storage tank to discharge of the treated water to East Fork Poplar Creek (EFPC).

\section{PROJECT REQUIREMENTS}

This project treats groundwater contaminated with mercury (Hg) from Bldgs. 9201-4, 9201-5, and 9204-4 to meet NPDES Permit limits for discharge to EFPC. The outfall for this system is designated as Outfall 551. The limits for Outfall 551 are 2 parts per billion (ppb) $\mathrm{Hg}$ for the monthly average, $4 \mathrm{ppb} \mathrm{Hg}$ for the daily maximum, and a pH between 6 and 9 .

The project's intent was to complete construction as early as possible, although the permit does not require a permanent system to be operational until January 1,1998 . The early completion date allows $\mathrm{Hg}$ concentrations in EFPC to be evaluated to determine whether further actions are required to meet NPDES permit limits for reduced $\mathrm{Hg}$ loading to the creek.

\section{REMEDIATION ACTIVITIES}

Activities on the CMTS included the removal of existing equipment and support services in Building 9623, advanced procurement of the carbon columns, and system installation. The Department of Energy (DOE) sent the specifications for the procurement of the carbon columns to the Tennessee Department of Environment and Conservation (TDEC) on June 23, 1995. Approval of the specification was received August 7, 1995 (see Appendix A). DOE then sent the project specifications and drawings for the system installation to TDEC on November 1, 1995; TDEC approved construction on December 19, 1995 (see Appendix B). TDEC's approval was not required for removal of the obsolete equipment and systems in Bldg. 9623. 
The specification for the carbon columns, prepared by Foster Wheeler Environmental Corporation, was issued for bid by MK-Ferguson, and on August 30, 1995, the bid was awarded to Water Control Associates, Inc. During the bid process, the winning bidder suggested a change in material from coated carbon steel to stainless steel. This change was accepted, resulting in a minor increase in the initial cost and large savings in the life cycle cost (future coating replacement/maintenance on the carbon steel will be avoided).

MK-Ferguson visited the vendor's manufacturing facility twice: once before final fabrication to inspect parts and material certifications and again after assembly to witness the final testing and inspection. The columns were shipped and arrived on-site the week of March 4, 1996. During the walkdown and inventory check after delivery, some minor nonconformances were reported. These were corrected before final acceptance and payment. The final acceptance date was August 30, 1996.

Based on a "make or buy" analysis, direct-hire forces performed the demolition and removal of the obsolete equipment and support systems in the 9623 area. The primary driver for keeping this work in-house was the uncertainty of the hazards that might have been encountered during removal. The demolition package was issued to MK-Ferguson on October 4, 1995, and a kick-off meeting was held on October 30, 1995. Section 5 summarizes the waste generated from this activity and the final destination and disposal. The initial effort for this work was completed by the end of December 1995.

As the area was cleared, additional items for removal were identified, and the direct-hire forces were kept on call to support the fixed-price subcontractor during the system installation phase. This allowed the use of trained in-house workers covered under an existing medical surveillance plan to perform work as required and avoid the additional cost of training and developing an approved plan by the subcontractor.

The construction drawings and specifications, prepared by Foster Wheeler Environmental Corporation, were issued for bid by MK-Ferguson, and the contract for the system installation was awarded to CMC Construction Company, Inc., on January 12, 1996. In addition to the installation of the carbon columns and supporting piping, pumps, and filters, the contract included the procurement and installation of two major systems. These systems were the Programmable Logic Controller (PLC) and the carbon dewatering system. The PLC monitors and controls system flows, reports alarm conditions, and shuts the system down if necessary. It includes a phone dial-out system that will call operations personnel during off-shift operations to alert them to an alarm condition. The carbon dewatering system will be used to remove excess water from the spent carbon before disposal.

During operational testing and checkout, which began in late September, numerous minor problems were discovered and added to the contractor's punch list for correction. System testing and construction proceeded in parallel until near the end of October. Testing of the system was completed in November. TDEC made its final walk-through on November 19, 1996 (see Appendix C), and the CMTS was placed into operation on November 26, 1996, following TDEC approval (Appendix D). 


\section{DEVIATIONS FROM APPROVED PLANS}

Several minor changes from the original plans were made to adjust to field conditions during construction. Theses changes included pipe routing and support locations, equipment foundation sizes, paint colors, etc. These changes are reflected in the final as-built drawings of the system.

The original design for processing water from the spent carbon was difficult and cumbersome to operate, so it was modified to increase operability. The original design allowed pumping from the bottom of the storage tank only. During operational checkout, this design was deemed unacceptable because of the amount of carbon solids being flushed into the tank. The modifications allowed water to be decanted from the top of the tank and the bottom slurry to be recycled to the dewatering hopper using a carbon bed to remove or reduce the amount of solids. Process water was also hard piped to the dewatering hopper so it could be used to backwash and clear the screens during operations. These changes are shown on the as-built drawings.

As mentioned in Sect. 3, the construction material for the carbon columns was changed from coated carbon steel to stainless steel because of a reduction in the life cycle cost.

\section{WASTE MANAGEMENT/TRANSPORTATION ACTIVITIES}

Waste generated by this project was segregated, characterized, and packaged to meet Waste Management Operations (WMO) waste acceptance criteria. Request for Disposal forms (UCN-2109) were completed for the different containers and types of waste. The project transported the sanitary waste to the Y-12 Sanitary Landfill (SLF). WMO picked up the hazardous/contaminated waste for disposal or storage per approved procedures depending on the type or mix of waste. The table below lists the 2109 numbers, the type of hazard or contamination, description, volume, and weight of the waste, and whether waste was disposed of at the landfill or managed by WMO.

Table 1. Disposition of waste generated by the CMTS project

\begin{tabular}{|c|c|c|c|}
\hline $2109 \#$ & Waste & Vol./wt & Disposition \\
\hline \multicolumn{4}{|l|}{ Sanitary } \\
\hline 201228 & Concrete & $15 \mathrm{ft}^{3} / 2250 \mathrm{lb}$ & SLF \\
\hline 201229 & Concrete & $7.5 \mathrm{ft}^{3} / 1125 \mathrm{lb}$ & SLF \\
\hline 048808 & Concrete & $22 \mathrm{ft}^{3} / 1800 \mathrm{lb}$ & SLF \\
\hline 048802 & HDPE & $12 \mathrm{yd}^{3} / 2000 \mathrm{Ib}$ & SLF \\
\hline 048811 & HDPE & $2.5 \mathrm{yd}^{3} / 500 \mathrm{lb}$ & SLF \\
\hline 048813 & Glass & $3 \mathrm{ft}^{3} / 50 \mathrm{lb}$ & SLF \\
\hline
\end{tabular}


Table 1. (continued)

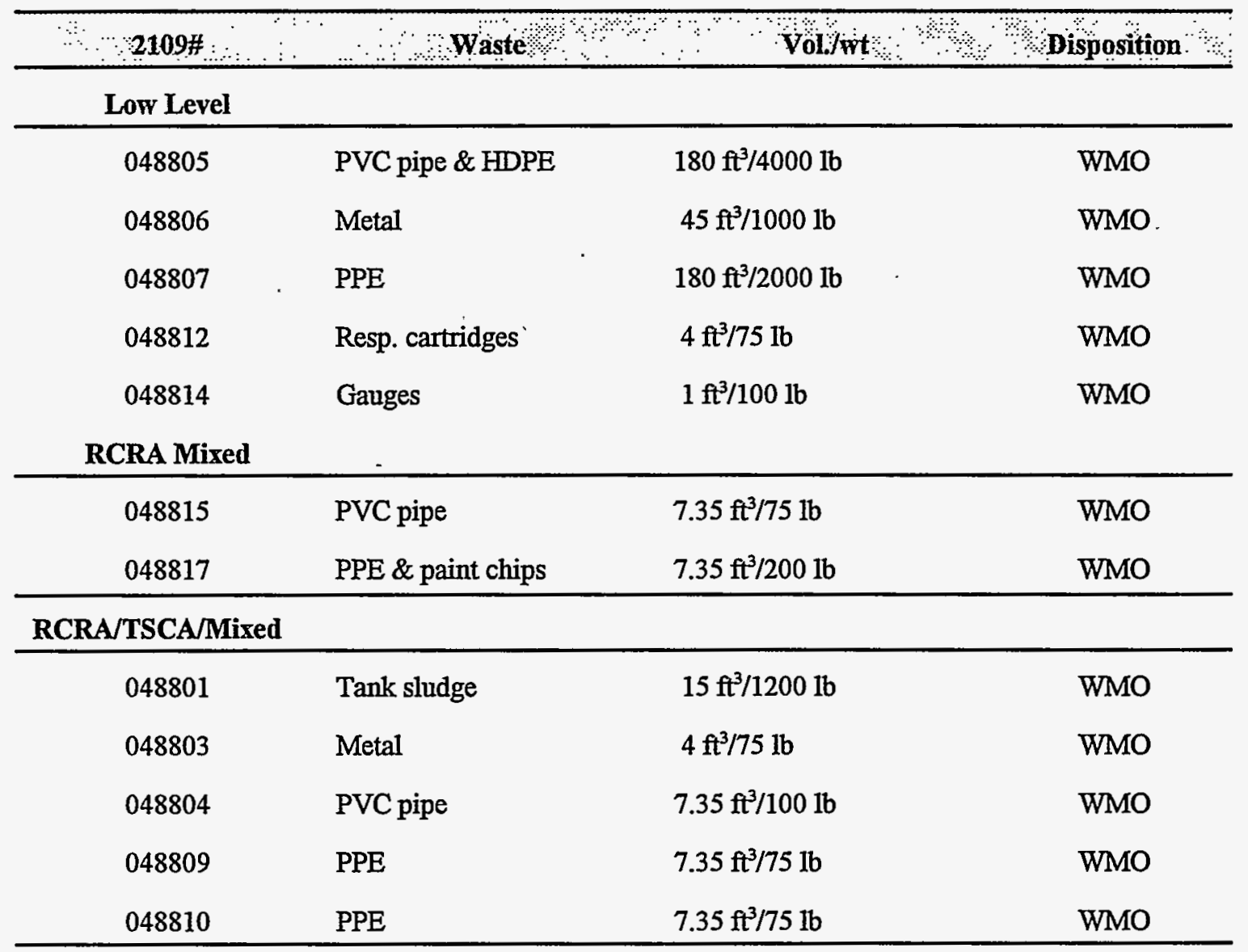

HDPE = high density polypropylene $\mathrm{PPE}=$ personal protective equipment $\mathrm{PVC}=$ polyvinyl chloride

\section{OPERATION AND MAINTENANCE PLANS}

No operation and maintenance plans have been detailed in any of the previous documentation. WMO will be responsible for the operation and maintenance of the system equipment. This includes carbon columns, system pumps, gauges and instrumentation, filter changes, etc. This work will be performed according to approved procedures and by trained workers.

The Compliance Monitoring Services Division will maintain the flow meters at $2100 \mathrm{U}$ and at Outfall 551 as well as the sampling equipment at the outfall and collect all NPDES compliance samples for reporting to TDEC. 


\section{MONITORING SCHEDULE AND/OR EXPECTATIONS}

The NPDES Permit requirements for this facility are included in the permit under Outfall 551. These requirements are:

- $\quad$ a pH between 6.0 and 9.0 as determined from a weekly grab sample;

- mercury content below $0.002 \mathrm{mg} / \mathrm{l}$ for a monthly average, with $0.004 \mathrm{mg} / \mathrm{l}$ as a daily maximum as determined from a 24-hr composite sample taken once a week; and

- submittal of a Form $2 \mathrm{C}$, which details discharge component parameters, within 2 years of the start of discharges from the outfall.

WMO will be sampling at several critical locations throughout the system to develop and follow trends in system performance to determine optimum maintenance schedules. 
Appendix A 



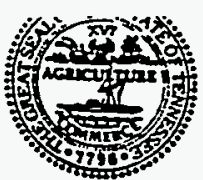

STATE OF TENNESSEE
DEPARTMENT OF ENVIRONMENT AND CONSERVATION
DOE OVERSIGHT DIVISION
761 EMORY VALLEY ROAD
OAK RIDGE, TENNESSEE 37830-7072

August 7, 1995

Mr. Nelson Lingle

US Department of Energy

PO Box 2001

Oak Ridge TN 37831

\section{EQUIPMENT SPECIFICATIONS FOR THE CENTRAL MERCURY TREATMENT SYSTEM} AT Y-12

Dear Mr. Lingle

The Tennessee Department of Environment and Conservation. DOE Oversight Division has received the above mentioned document. Our staff has reviewed this document and determined it to be in accordance with the requirements of equipment specifications as stated in 1200-4-2-.05 of the TDEC rules. The equipment specifications for this project are hereby approved.

Additionally, engineering plans must be approved by this office prior to the actual construction of this project. If you have any questions, please contact Herschel Hall of my staff at 481-0097.

Sincerely

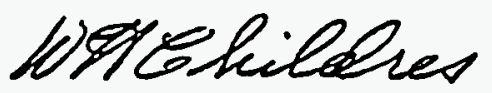

William H. Childres. PE, Manager

Waste Management Section

wm0906.10 
Appendix B 



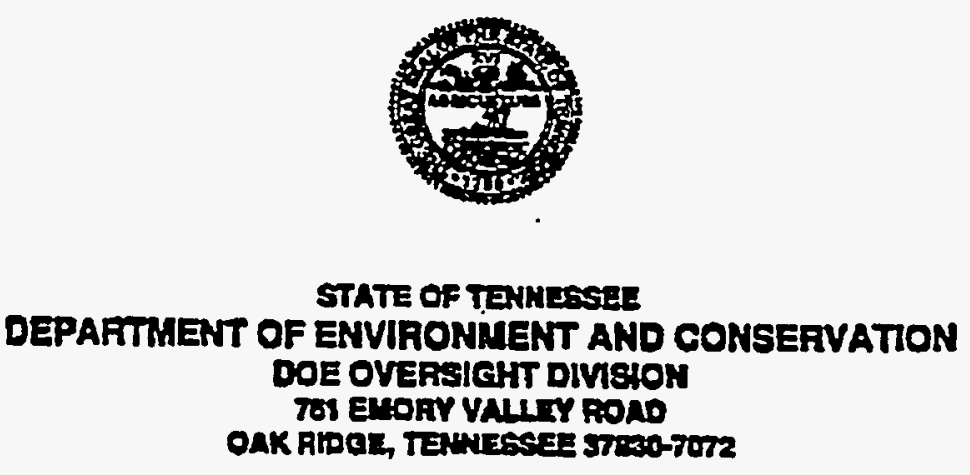

December 19, 1995

Mr. Neison Lingle

US Department of Energy

Oak Ridge Operations Office

PO Box 2001

Oak Ridge TN 37831

Dear Mr. Lingle

\section{CENTRAL MERCURY TREATMENT SYSTEM ENGINEERING PLANS AND SPECIFICATIONS}

The Temessee Department of Environment and Conservation, Deparment of Energy Oversight Division(TDEC/DOE-0) has received copies of the engineering drawings associated with the above mearioned project. These plans have been reviewed by the IDEC/DOE-O office and are hereby approved for construction. However, this approval is contingent on the conditions listed below:

Approval of these plans does not imply approval of any construction activity which may adversely affect local streams. Waters of the State shall not be altered nor polluted by erosion or any other activity associated with this project.

The approval for this project is granted in accordance with the requirements of the Tennessee Wate Pollution Control Act and the rules promulgated thereunder. However, this approval shall not be construed as ereating a presumption of correct operation or as warranting by the Commissioner that the approved facilities will meet the desired goals of the project.

TDECIDOE-O shall be notified at the beginning of construction At the completion of the construction phase of the project personnal from the TDEC/DOE-O office shall concuct a final inspection before the system will be permitted to begin operation. 
Nelson Lingle

Page Two

December 22, 1995

If you have any questions. please contact C. Herschel Hall of my staff at (423) 481-0097.

Sincerely

WHEhilerer

William H. Childres, P.E., Manager

Waste Management Program

cc: Larry Bunting 
Appendix C

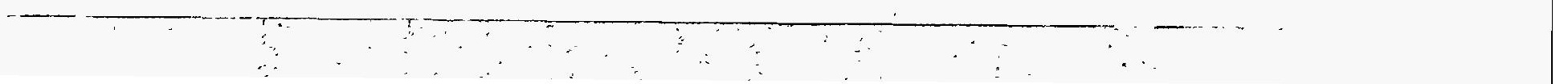





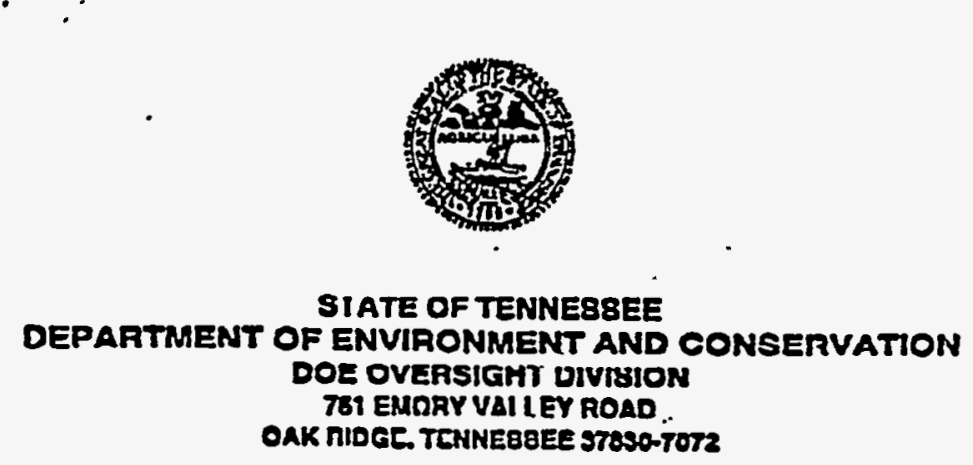

November 21, 1996

Mr. Robort Slocman

Environmontal Rostoration Division

Dopartment of Energy

PO Box 2001

Oak Ridgc, Tennessce 37831

Dear Mr. Slecman

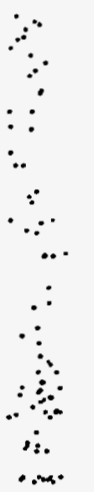

CRNTRAL MERCURY TREATMËIT SYSTEM (CMTS) Y-12 PLANT, OAK RIDGE, TENNESSE. $\because$

Rapresentatives from the Tennessec Department of Environment and Consorvation, Department of Encrgy Oucrsight IJivision (IDEC CJDOE.O) has revicwed the wastewater treatment facility associsted with the abovi referenced prnject. 'The trentment facility consists of earton adsorption units, filters, carbon dewatering syste and assnciated piping and tanks.

Following discussions with CMTS design engincers and operations peersonnel and a site visit, the Division is , the opinion that the CMTS has been constitucted according to the approved enginecring plans. 1OHF is herch! approved to begin operation of the CMTS. Written notification at commencement of operation is requested.

If you have any questions. please contact C. Herschel Hall at $481-0097$.

Sincetcly

wt Lefildren.

Williurn H. Childres. P.E.

Mautuger. Wuste Mantugement Program

ce Larry Buuling, TDEC, WPC Robert Spence, DOE Mike Travagliui, DOE David Level, DOE

wm005.01

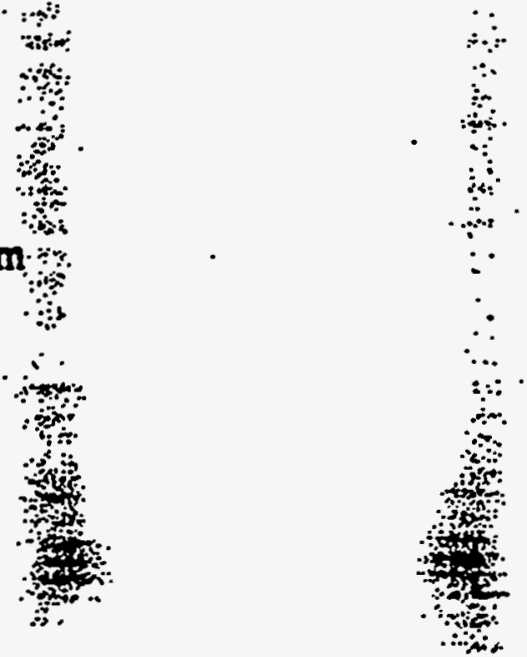


Appendix D 

December 18, 1996

Mr. R. C. Sleeman, Director

Environmental Restoration Division

Department of Energy, Oak Ridge Operations

Post Office Box 2001

Oak Ridge, Tennessee 37831

Dear Mr. Sleeman:

\section{Contract DE-AC05-840R21400, Central Mercury Treatment System (CMTS), Y-12 Plant, Oak Ridge, Tennessee}

The CMTS was officially declared operational at $10 \mathrm{am}$. on November 26, 1996. This follows completion of construction, test and checkout, and Tennessee Department of Environment and Conservation (TDEC) approval to operate (reference TDEC/Department of Energy, Oversight Division [DOE-O], letter from W. H. Childress to you, dated November 21, 1996). Mr. Childress's rapid response to a request for a facility inspection, which was held November 19 , and his approval to operate were greatly appreciated.

The operation of the CMTS comes 13 months prior to the National Pollutant Discharge Elimination System Permit required date of January 1,1998 , and is expected to remove approximately three to four grams per day of mercury loading in East Fork Poplar Creek. Facility as-built drawings will be forwarded in January 1997.

Please provide the above information to Mr. Paul Davis and Mr. Larry Bunting of the Nashville TDEC office and Mr. Earl Leming and Mr. Bill Childress of the TDEC/DOE-O office.

If you have any questions, please contact $E$. T. Collins at 574-8886.

Very truly yours,

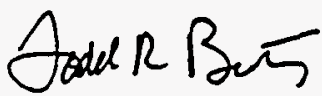

T. R. Butz

Y-12 Plant Manager

TRB:bjs

cc: R. E. Bell

T. R. Butz

E. T. Collins

F. P. Gustavson

R. M. Keyser/J. E. Powell

D. Level, DOE-ORO
S. D. Morris, DOE-ORO

M. A. Travaglini, DOE-ORO

J. H. Vanderlan

L. O. Vaughan

File-EMD-RC 


\section{DISTRIBUTION}

1. L. V. Asplund

2. W. H. Bessom

3. K. M. Bracic

4. K. A. Bradley

5. R. H. Bunchman

6. C. K. Chase

7. E. T. Collins

8. K. W. Cook

9. D. G. Cope

10. L. A. Felton

11. C. S. Haase

12. B. L. Kimmel

13. B. D. Kurtz

14. D. M. Matteo

15. H. C. Newsom

16. P. T. Owen

17. G. M. Powers

18. F. R. Trent

19. J. H. Vanderlan

20. A. R. Winningham

21. File-EMEF DMC-RC

22. J. A. Baker, Foster Wheeler Environmental Corporation, FEDC, MS 8218

23. K. A. Cruikshank, Foster Wheeler Environmental Corporation, FEDC, MS 8218

24. F. C. Larvie, MK-Ferguson, Bldg. 9114, MS 8178.

25. L. A. Wessell, MK-Ferguson, Bldg. 9983-81, MS 8178 